\title{
PENGARUH PENGETAHUAN PERPAJAKAN, SELF-ASSESSMENT SYSTEM, SANKSI PAJAK, PENERAPAN Q-SPT DAN NASIONALISME TERHADAP KEPATUHAN WAJIB PAJAK DALAM MELAPORKAN SPT TAHUNAN
}

\author{
Tirza Yulianti \\ Endang Satyawati \\ Program Studi Akuntansi, Fakultas \\ Ekonomi Universitas Kristen Surakarta \\ Email korespondensi: endangsatyawati@uks.ac.id
}

\begin{abstract}
ABSTRAK
Tujuan penelitian ini adalah untuk mendapatkan bukti empiris bahwa secara parsial dan simultan pemahaman Wajib Pajak terhadap pengetahuan perpajakan, self-assessment system, penerapan e-SPT dan nasionalisme berpengaruh positif terhadap kepatuhan Wajib Pajak di PT BMK. Teknik pengumpulan data pada pemilihan sampel dalam penelitian ini menggunakan kuesioner dan diisi oleh 50 Wajib Pajak terdiri dari karyawan dan sales force PT BMK. Analisis data yang digunakan adalah regresi analisis. Hasil analisis menunjukan bahwa variabel pengetahuan perpajakan berpengaruh positif terhadap kepatuhan Wajib Pajak. Begitu juga untuk self-assessment system pengaruh positif terhadap kepatuhan Wajib Pajak. Begitu juga untuk sanksi pajak berpengaruh positif terhadap kepatuhan Wajib Pajak. Begitu juga penerapan e-SPT berpengaruh positif terhadap kepatuhan Wajib Pajak. Begitu juga nasionalisme berpengaruh positif signifikan terhadap kepatuhan Wajib Pajak.
\end{abstract}

Kata Kunci: e-SPT, sanksi pajak, kepatuhan, nasionalisme

\begin{abstract}
The objective of this study is to obtain empirical evidence of understanding Taxpayers' knowledge of taxation, self assessment system, application of e-SPT and nationalism has a positive effect on taxpayer compliance at PT BMK partially and simultaneously.Data collection technique in the selection of samples in this study uses a questionnaire and filled by 50 taxpayers consisting of employees and sales force of PT BMK. Analysis of the data used is multiple regression analysis. The result of the analysis shows that the tax knowledge variable has a positive effect on taxpayer compliance. The self-assessment system has positive effect on compliance with Taxpayers. Tax sanctions has significantly positive effect on compliance with Taxpayers. The application of e-SPT has a significant positive effect on taxpayer compliance. Nationalism has a significant positive effect on PT BMK taxpayer compliance.
\end{abstract}

Keywords: $e-S P T$, tax sanctions, compliance, nationalism 


\section{PENDAHULUAN}

Pada era globalisasi, Indonesia dihadapkan pada tuntutan perkembangan berbagai bidang agar dapat menjaga stabilitas negara. Pemenuhan tuntutan tersebut diwujudkan dalam suatu Anggaran Pendapatan dan Belanja Negara yang mengelompokkan pendapatan negara menjadi dua, yakni Penerimaan Negara dan Hibah. Penerimaan Negara terbagi menjadi Penerimaan Perpajakan dan Penerimaan Negara Bukan Pajak.

Sektor pajak memang masih menjadi salah satu sumber penerimaan utama negara yang masih terus digali potensinya oleh pemerintah dalam rangka membiayai pembangunan nasional. Kenaikan penerimaan sektor pajak dari tahun ke tahun menunjukkan bahwa terdapat potensi besar di sektor perpajakan. Kenaikan penerimaan pajak ini tentu akan turut meningkatkan penerimaan kas negara yang dapat digunakan sebesar-besarnya untuk pembangunan nasional. Jika dibandingkan dengan jenis pajak lainnya, pajak penghasilan memiliki proporsi paling besar.

Populasi masyarakat Indonesia yang sangat banyak menjadikan potensi pajak sangat tinggi, namun demikian kesadaran masyarakat terhadap kewajiban setiap warga negara dalam membayar pajak masih sangat rendah. Hal ini menjadi tugas pemerintah sebagai penyelenggara pajak untuk terus melakukan sosialisasi pajak, serta menemukan terobosanterobosan yang dapat meningkatkan kesadaran dan kepatuhan wajib pajak dalam memenuhi kewajiban perpajakannya.

Pemerintah mampu merealisasikan penerimaan pajak senilai Rp 1.055 triliun pada 2015. Jumlah tersebut mencapai 81,5 persen dari yang ditargetkan dalam Anggaran Penerimaan dan Belanja Negara Perubahan 2015 yang tercatat Rp 1.294,25 triliun. Selanjutnya pajak secara keseluruhan per 31 Desember 2016 mencapai Rp1.105 trilliun atau sebesar 81.54 persen dari target penerimaan pajak APBN Perubahan 2016 sebesar Rp1.533 trilliun. Realisasi penerimaan pajak di atas menunjukkan penerimaan negara secara total tumbuh sekitar 4,13 persen dibandingkan dengan tahun 2015. Meskipun dari tahun 2015 dan 2016 terdapat kenaikan pendapatan pajak akan tetapi jumlah angka yang dihasilkan masih terlihat lebih rendah dari pada angka yang ditargetkan pada Anggaran Penerimaan dan Belanja Negara
Perubahan , sehingga dalam hal ini pemerintah harus berusaha lebih giat dalam meningkatkan penerimaan pajak agar mencapai target .

Selain itu, rasio kepatuhan pada tahun 2017 mengalami penurunan hanya 52,1\% dari tahun 2016 sebesar 60,47\%. Target penerimaan pajak akan selalu mengalami kenaikan setiap tahunnya seiring dengan kegiatan intensifikasi terhadap wajib pajak terdaftar dan kegiatan ekstensifikasi dalam mengumpulkan wajib pajak baru yang dilakukan KPP Pratama Surakarta . Melihat kondisi seperti ini menurut Siti Kurnia dalam meningkatkan kepatuhan wajib pajak menuntut keikutsertaan aktif Wajib Pajak dalam menyelenggarakan perpajakannya untuk menumbuhkan kepatuhan Wajib Pajak yang tinggi, yaitu kepatuhan dalam pemenuhan kewajiban perpajakan yang sesuai dengan kebenarannya.

Salah satu faktor yang mempengaruhi kepatuhan adalah pengetahuan wajib pajak tentang tata cara melaksanakan kewajiban perpajakan. Semakin tinggi tingkat pendidikan atau pengetahuan wajib pajak, maka semakin mudah pula bagi mereka untuk memahami peraturan perpajakan dan semakin mudah pula wajib pajak memenuhi kewajiban perpajakannya . Penelitian Caroko et al. menunjukkan bahwa kepatuhan Wajib Pajak dipengaruhi oleh pengetahuan pajak yang ditunjukkan oleh nilai koefisien korelasi sebesar 0,888 dan nilai koefisien determinasi sebesar $37,12 \%$, sehingga termasuk ke dalam kriteria kurang baik dengan arah positif. Arah hubungan positif menunjukkan bahwa Pengetahuan Pajak yang kurang baik akan diikuti dengan tingkat Kepatuhan Wajib Pajak yang kurang baik pula dan kontribusi Pengetahuan Pajak sebesar 37,12\% terhadap Kepatuhan Wajib Pajak.

Pengetahuan perpajakan sangat penting dimiliki oleh wajib pajak. Hal tersebut sesuai dengan sistem yang berlaku di Indonesia yaitu self-assessment system yang mewajibkan wajib pajak mengetahui segala alur pemenuhan kewajiban perpajakannya mulai dari tahap awal yaitu menghitung, memperhitungkan sampai dengan melapor kewajiban perpajakannya. Tujuan yang diharapkan dari pelaksanaan sistem ini adalah kesadaran wajib pajak, kejujuran wajib pajak, hasrat untuk membayar pajak atau tax mindness wajib pajak dan tax decipline wajib pajak dalam melaksanakan aturan perundang-undangan 
perpajakan . Faktor Self-Assessment System juga berpengaruh terhadap kepatuhan wajib pajak.

Sanksi perpajakan yang sudah diterapkan ini diharapkan dapat memberikan efek jera kepada wajib pajak yang melanggar ketentuan perpajakan. Pelaksanaan perpajakan di Indonesia tidak lepas dari Direktorat Jendral Pajak yang memiliki tanggung jawab dalam memaksimalkan penerimaan negara dalam sektor pajak. DJP sebagai lembaga pemerintah yang dipercaya dalam hal perpajakan di Indonesia, maka DJP melakukan reformasi perpajakan berupa modernisasi sistem administrasi perpajakan. Modernisasi sistem administrasi perpajakan adalah penyempurnaan kebijakan perpajakan dan sistem administrasi perpajakan yang berlaku, sehingga potensi penerimaan pajak yang tersedia dapat dipungut secara optimal .

Penyempurnaan kebijakan pajak tersebut ditujukan untuk memberikan fasilitas kepada wajib pajak sebagai bentuk kemudahan dalam memenuhi kewajiban perpajakan. Salah satu bentuk peningkatan kualitas pelayanan adalah dikembangkannya pelaporan pajak terutang dengan menggunakan Surat Pemberitahuan elektronik (e-SPT) . Pasal 1 angka 11 UndangUndang tentang Ketentuan Umum dan Tata Cara Perpajakan disampaikan bahwa Surat Pemberitahuan adalah Surat yang oleh wajib pajak digunakan untuk melaporkan perhitungan dan/atau pembayaran pajak, objek pajak, dan/atau harta dan kewajiban menurut ketentuan perundang-undangan perpajakan.

Reformasi administrasi perpajakan dilakukan oleh DJP sebagai bentuk peningkatan kualitas pelayanan perpajakan terhadap Wajib Pajak , salah satunya dikembangkannya pelaporan pajak terutang dengan menggunakan elektronik SPT . Dengan adanya pengaruh pengetahuan perpajakan wajib pajak, pengetahuan terhadap e-SPT, Sanksi Pajak, Self-Assessment System dan rasa Nasionalisme, diharapkan untuk setiap Wajib Pajak akan lebih mudah melaporkan SPT Tahunan nya. Hal ini ditujukan agar target penerimaan pajak tercapai dengan disertai fasilitas-fasilitas pajak dan kepatuhan pajak dalam membayar kewajibannnya.

Berdasarkan latar belakang di atas dan hasil-hasil peneltian terdahulu yang ada, peneliti melakukan penelitian lebih lanjut pada melaporkan SPT Tahunan pada perusahaan manufaktur. Peneliti tertarik untuk melakukan penelitian dengan judul Pengaruh Pengetahuan Perpajakan, Self-Assessment System, Sanksi Pajak, Penerapan e-SPT dan Nasionalisme Terhadap Kepatuhan Wajib Pajak Dalam Melaporkan SPT Tahunan (Studi Kasus pada Wajib Pajak di PT Bumi Manunggal Kharisma Surakarta).

Penelitian yang saya teliti ini adalah penelitian replikasi dari penelitian terdahulu yaitu penelitian dari Titis Wahyu Adi yang berjudul Pengaruh Pengetahuan Perpajakan, Sanksi Pajak, Kesadaran WP Terhadap Kepatuhan WP Badan KPP Cilacap 2018. Perbedaan penelitian saya ini dengan penelitian terdahulu terletak pada tempat penelitian nya yang dilakukan di Kantor Pelayanan Pajak Kabupaten Cilacap dengan penelitian saya saat ini dilakukan di Kantor PT Bumi Manunggal Kharisma Surakarta. Lalu waktu penelitian terdahulu dilaksanakan pada bulan Maret-April 2018 sedangkan penelitian saya dilakukan pada bulan Januari-Maret 2020. Lalu variabel penelitian terdahulu yaitu Pengetahuan Perpajakan, Sanksi Pajak, Terhadap Kepatuhan WP Badan KPP Cilcap 2018. Sedangkan variabel penelitian saya adalah Pengetahuan Perpajakan, Self Assessment System, Sanksi Pajak, Penerapan e-SPT, Nasionalisme dan Terhadap Kepatuhan Wajib Pajak dalam Melaporkan SPT Tahunan. Tujuan dari penelitian ini adalah untuk menganalisis pengaruh pengetahuan perpajakan, self assessment system, sanksi pajak, penerapan eSPT dan nasionalisme terhadap kepatuhan wajib pajak dalam menyampaikan SPT Tahunan.

\section{KAJIAN LITERATUR}

\section{Konsep Pajak}

Pajak adalah iuran masyarakat kepada negara (yang dapat dipaksakan) yang terutang oleh orang yang wajib membayarnya menurut peraturan-peraturan umum (undang-undang) dengan tidak mendapat prestasi kembali yang langsung dapat ditunjuk yang gunanya adalah untuk membiayai pengeluaran-pengeluaran umum berhubung tugas negara untuk menyelenggarakan pemerintahan. Dari pengertian tersebut dapat diketahui bahwa pajak dapat bersifat memaksa, dipungut oleh 
pemerintah dan diatur dalam undang-undang (Ria Prasasti, 2016: 12). Masyarakat diharapkan mampu memahami bahwa fungsi pajak digunakan untuk kepentingan seluruh masyarakat, bukan hanya untuk kepentingan seseorang ataupun sekelompok orang. Pajak menjadi sumber penerimaan yang dominan di Indonesia. Perekonomian Indonesia sangat bergantung pada sektor pajak dalam membiayai pengeluaran negara karena rendahnya proporsi penerimaan di sektor bukan pajak. Oleh karena itu diharapkan penerimaan di sektor pajak dapat ditingkatkan melalui peningkatan kepatuhan Wajib Pajak dalam memenuhi kewajiban perpajakannya.

\section{Konsep Wajib Pajak}

Wajib pajak adalah orang pribadi atau badan yang menurut ketentuan peraturan perundang-undangan perpajakan ditentukan untuk melakukan kewajiban perpajakan, termasuk pemungut pajak atau pemotong pajak tertentu.

\section{Konsep Pengetahuan Pajak}

Pengetahuan pajak adalah mengerti mengenai konsep ketentuan umum di bidang pajak dan jenis pajak yang berlaku di Indonesia mulai dari objek pajak, subjek pajak, perhitungan pajak terutang, tarif pajak. pencatatan pajak terutang, sampai pada pembayaran dan pelaporan. Pengetahuan perpajakan ini tidak hanya pemahaman konseptual berdasarkan Undang-undang Perpajakan, keputusan Menteri Keuangan, Surat Edaran, Surat Keputusan tetapi juga adanya tuntutan kemampuan atau ketrampilan teknis bagaimana menghitung besarnya pajak yang terutang (Supriyati, 2011).

\section{Konsep Self-Assesment System}

Berdasarkan UU KUP No.28 tahun 2007, sistem yang berlaku di Indonesia adalah Self-Assessment System. Self-Assessment System merupakan sistem yang memberikan kepercayaan penuh kepada masyarakat selaku wajib pajak dalam melaksanakan kewajiban perpajakan. Kewajiban perpajakan yang dimaksud adalah "mendaftar, menghitung, membayar, dan melaporkan pajaknya sesuai dengan ketentuan perpajakan yang berlaku”. Self-Assessment System secara tidak langsung mengharuskan wajib pajak untuk memahami peraturan perpajakan agar mempermudah wajib pajak dalam melaksanakan kewajiban perpajakan dengan benar.

\section{Konsep Sanksi Pajak}

Sanksi berasal dari bahasa Belanda yaitu Sanctie yang artinya ancaman hukuman, merupakan suatu alat pemaksa guna ditaatinya suatu kaidah, Undang-Undang misalnya sanksi terhadap pelanggaran suatu Undang-Undang. Sanksi adalah alat pemaksa, dimana sanksi memaksa menegakkan hukum atau memaksa mengindahkan norma-norma hukum. Sanksi sebagai alat penegak hukum bisa juga terdiri atas kebatalan perbuatan yang merupakan pelanggaran hukum. Baik batal demi hukum maupun batal setelah ini dinyatakan oleh hakim (Titis, 2018: 35).

\section{Konsep e-SPT}

Kepatuhan wajib pajak dalam penerapan e-SPT dapat ditunjang dengan pengetahuan perpajakan yang telah diketahui oleh wajib pajak itu sendiri, karena kewajiban pajak yang terkait dalam penerapan e-SPT yaitu mendaftar, menghitung, membayar, dan melaporkan pajak sesuai dengan penghasilan yang didapat oleh wajib pajak tersebut. Pengetahuan perpajakan yang dimiliki oleh wajib pajak dapat dinilai menjadi faktor dalam meningkatkan kepatuhan perpajakan oleh wajib pajak, karena semakin tinggi pengetahuan yang dimiliki oleh wajib pajak dinilai dapat mempengaruhi peningkatan kepatuhan wajib pajak dalam melaksanakan kewajiban perpajakan (Gustiyani, 2014:7).

\section{Konsep Nasionalisme}

Nasionalisme adalah (1) paham (ajaran) untuk mencintai bangsa dan negara sendiri; sifat kenasionalan: makin menjiwai bangsa Indonesia; (2) kesadaran keanggotaan dalam suatu bangsa yang secara potensial atau aktual bersama-sama mencapai, mempertahankan, dan mengabadikan identitas, integritas, kemakmuran, dan kekuatan bangsa itu; semangat kebangsaan. Dari definisi di atas, dapat ditarik kesimpulan bahwa rasa nasionalisme dapat ditunjukkan dengan adanya partisipasi warga negara terhadap pembangunan dan juga dalam menegakkan hukum serta keadilan sosial agar mencapai kehormatan suatu bangsa. Dengan adanya sikap nasionalisme diharapkan akan menumbuhkan sikap saling menghargai, menghormati, dan juga timbul kerjasama yang baik dengan bangsa 
lain. Nasionalisme sangatlah dibutuhkan dalam perpajakan, karena pajak sendiri merupakan iuran wajib yang sifatnya memaksa dimana yang memberikan pajak tidak merasakan manfaat dari pajak secara langsung, karena pajak digunakan untuk kepentingan umum. Oleh karena itu, diharapkan rasa nasionalisme yang tertanam dalam diri setiap wajib pajak dapat mengurangi risiko ketidakpatuhan wajib pajak dalam memenuhi kewajiban perpajakannya karena rasa cintanya terhadap tanah air.

\section{Konsep Kepatuhan Pajak}

Definisi kepatuhan menurut PPh Pasal 25 wajib pajak pribadi adalah pembayaran kewajiban pajak yang dilaporkan tepat waktu. Berdasarkan uraian ringkas tersebut dapat disimpulkan bahwa kepatuhan menunjukkan kesadaran diri untuk melakukan pembayaran pajak secara sukarela tepat pada waktunya. Dalam definisi yang lebih luas kepatuhan pajak dapat didefinisikan sebagai sikap moral untuk secara sukarela melakukan pembayaran pajak hingga tenggang waktu yang ditetapkan. Semakin tinggi tingkat kebenaran menghitung dan memperhitungkan, ketepatan menyetor, serta mengisi dan memasukkan surat pemberitahuan (SPT) wajib pajak, maka diharapkan semakin tinggi tingkat kepatuhan wajib pajak dalam melaksanakan dan memenuhi kewajiban pajaknya (Tika, 2016).

\section{PENGEMBANGAN HIPOTESIS}

\section{Pengaruh Pengetahuan Perpajakan Terhadap Kepatuhan Wajib Pajak dalam Melaporkan SPT Tahunan}

Kurangnya pengetahuan perpajakan oleh wajib pajak dapat menjadi kendala dalam pelaksanaan kewajiban perpajakan, oleh karena itu untuk mengatasi kurangnya pengetahuan perpajakan adalah dengan dilaksanakannya sosialisasi perpajakan. Pandangan masyarakat kan kalau bayar pajak uang pajak dikemanakan. Oleh karena itu sosialisasi pengetahuan mengenai pajak sangat perlu ditingkatkan khususnya dikalangan generasi muda (Rasjid, 2014).

Pernyataan oleh Rasjid terebut menjelaskan bahwa pengetahuan perpajakan oleh masyarakat dinilai masih rendah. Dengan wajib pajak memahami pengetahuan perpajakan maka wajib pajak dapat mengetahui kewajiban yang harus dilakukan dalam hal perpajakan. Kurangnya pengetahuan Wajib Pajak akan hak dan kewajibannya serta penerapan sanksi perpajakan mengakibatkan rendahnya kesadaran dalam membayar pajak.

$\mathrm{H}_{1}$ : Pengetahuan perpajakan berpengaruh terhadap kepatuhan wajib pajak dalam melaporkan SPT tahunan.

Pengaruh Self Assesment System terhadap Kepatuhan Wajib Pajak dalam Melaporkan SPT Tahunan

Self-assessment system merupakan sistem pemungutan yang memberikan kewenangan penuh kepada WP untuk melakukan kewajiban perpajakannya. Kewajiban yang harus dilakukan yaitu menyampaikan SPT dengan benar dan tepat waktu. Penelitian Septiani (2014) menunjukkan bahwa variabel penerapan self assessment system berpengaruh secara signifikan terhadap kepatuhan wajib pajak, sedangkan variabel kemauan membayar pajak berpengaruh secara signifikan terhadap kepatuhan wajib pajak. Hasil penelitian Satyawati dan Cahjono (2017) menemukan bahwa penerapan Self Assessment System berpengaruh signifikan terhadap Kepatuhan Wajib Pajak.

$\mathrm{H}_{2}$ : Self Assessment System berpengaruh terhadap kepatuhan wajib pajak dalam melaporkan SPT tahunan.

\section{Pengaruh Sanksi Pajak Terhadap Kepatuhan Wajib Pajak dalam Melaporkan SPT Tahunan}

Penelitian Masruroh dan Zulaikha (2013) wajib pajak akan patuh membayar pajak bila memandang sanksi perpajakan akan lebih banyak merugikannya. Sanksi perpajakan bertujuan untuk memberikan efek jera kepada wajib pajak yang melanggar norma perpajakan sehingga tercipta kepatuhan wajib pajak dalam melaksanakan kewajiban perpajakannya.

Penelitian yang dilakukan oleh Dian Lestari Siregar (2017) menemukan bahwa Sanksi Pajak berpengaruh signifikan terhadap Kepatuhan Wajib Pajak Orang Pribadi. Sanksi perpajakan yang tegas bagi pelanggar ketentuan perpajakan akan menciptakan rasa takut kepada Wajib Pajak untuk lalai dalam memenuhi kewajibannya dalam membayar pajak. 
$\mathrm{H}_{3}$ : Sanksi pajak berpengaruh terhadap kepatuhan wajib pajak dalam melaporkan SPT tahunan.

Pengaruh Penerapan e-SPT terhadap Kepatuhan Wajib Pajak dalam Melaporkan SPT Tahunan

Penggunaan e-SPT dimaksudkan agar semua proses kerja dan pelayanan perpajakan berjalan dengan baik, lancar, akurat serta mempermudah WP dalam melaksanakan kewajiban perpajakannya sehingga kepatuhan pajak diharapkan akan meningkat. Pentingnya keberhasilan dari implementasi e-SPT sebagai salah satu faktor yang memengaruhi kepatuhan pajak didukung oleh hasil penelitian-penelitian sebelumnya antara lain penelitian Christian Hidayat (2011) yang menyimpulkan bahwa penerapan e-SPT PPN berpengaruh secara signifkan terhadap kualitas informasi perpajakan, dan Lingga (2013) yang menyimpulkan bahwa penerapan e-SPT dan $e$ Filling memiliki pengaruh positif signifikan terhadap kepatuhan wajib pajak.

$\mathrm{H}_{4}$ : Penerapan e-SPT berpengaruh terhadap kepatuhan wajib pajak dalam melaporkan SPT tahunan.

\section{Pengaruh Nasionalisme Terhadap Kepatuhan Wajib Pajak dalam Melaporkan SPT Tahunan}

Nasionalisme adalah suatu paham, yang berpendapat bahwa kesetiaan tertinggi individu harus diserahkan kepada negara kebangsaan. Berdasarkan teori atribusi, nasionalisme merupakan penyebab internal yang dapat mempengaruhi persepsi wajib pajak dalam membuat keputusan mengenai perilaku kepatuhan wajib pajak dalam melaksanakan kewajiban perpajakannya.

Perumusan hipotesis ini mengacu pada penelitian Purnamasari (2017) dimana nilai koefisien regresi variabel nasionalisme sebesar
0,296 menyatakan apabila terjadi peningkatan nasionalisme sebesar satu satuan sedangkan variabel lain tetap, maka akan meningkatkan kepatuhan wajib pajak dalam membayar PBB sebesar 0,296. Berdasarkan penjelasan diatas dapat diambil hipotesis sebagai berikut:

$\mathrm{H}_{5}$ : Nasionalisme berpengaruh terhadap kepatuhan wajib pajak dalam melaporkan SPT tahunan.

Pengaruh Pengetahuan Pajak, SelfAssessment System, Sanksi Pajak, Penerapan e-SPT dan Nasionalisme Terhadap Kepatuhan Wajib Pajak dalam Melaporkan SPT Tahunan

Pengetahuan perpajakan memberikan pembelajaran pada setiap wajib pajak yang mau melaporkan pajaknya. Dibantu dengan SelfAssessment System yang memberi kewenangan penuh pada Wajib pajak akan lebih membantu dalam melaporkan pajak. Selain itu sanksi pajak akan memberi efek jera ataupun pidana untuk yang tidak taat melapor. Penerapan eSPT yang juga mempermudah untuk proses melaporkan pajak sehingga diharapkan dapat meningkatkan kepatuhan wajib pajak dan rasa Nasionalisme yang menggerakkan nurani juga pikiran individu untuk taat dalam melaporkan pajak.

Perumusan hipotesis ini mengacu pada penelitian Ria Prasati (2016) yang menunjukan pengetahuan perpajakan dan sanksi pajak mempengaruhi Kepatuhan Wajib Pajak di Kanwil DJP DIY. Menurut (Firdaus ,2015) Peneraan e-SPT dan pengetahuan perpajakan berpengaruh signifikan terhadap kepatuhan wajib pajak.

H6: Pengetahuan Pajak, Self Assessment System, Sanksi Pajak, Penerapan e-SPT dan Nasionalisme berpengaruh terhadap kepatuhan wajib pajak dalam melaporkan SPT tahunan.

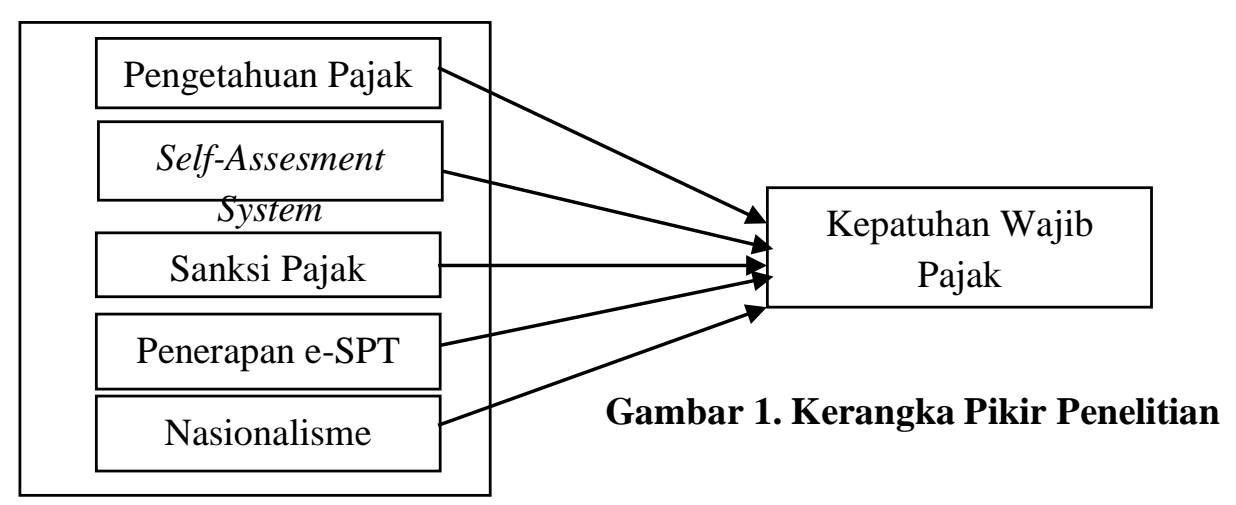




\section{METODE}

Pendekatan penelitian ini adalah pendekatan kuantitatif. Menurut Sugiyono (2013), penelitian kuantitatif adalah data yang berbentuk angka atau kualitatif yang diangkakan. Penelitian ini juga termasuk dalam penelitian survei. Menurut Indriantoro dan Supomo (2009: 152), metode survei merupakan metode pengumpulan data primer yang diperoleh secara langsung dari sumber asli (tidak melalui media perantara). Data primer secara khusus dikumpulkan oleh peneliti untuk menjawab pertanyaan penelitian. Metode ini memerlukan adanya kontak atau hubungan antara peneliti dengan responden. Metode survei merupakan metode pengumpulan data primer yang menggunakan pertanyaan lisan dan tertulis. Jenis penelitian ini adalah penelitian kausal komparatif (causal comparative research) dengan objek analisis yang diteliti adalah Wajib Pajak Orang Pribadi yang bekerja di PT Bumi Manunggal Kharisma Surakarta.

Penelitian ini dilaksanakan di PT Bumi Manunggal Kharisma Surakarta. Waktu penelitian dilaksanakan pada bulan Januari 2020 sampai Maret 2020. Sampel dalam penelitian ini adalah karyawan dan sales force PT Bumi Manunggal Kharisma Surakarta yang sudah mempunyai NPWP, yaitu sekitar 50 orang.

\section{Jenis Variabel}

Variabel Dependen

Variabel dependen adalah jenis variabel yang dijelaskan atau dipengaruhi oleh variabel independen. Variabel dependen atau terikat dalam penelitian ini adalah Kepatuhan Wajib Pajak dalam menyampaikan SPT tahunan. Kepatuhan Wajib Pajak dapat didefinisikan sebagai sikap moral untuk secara sukarela melakukan pembayaran pajak hingga tenggang waktu yang ditetapkan. Semakin tinggi tingkat kebenaran menghitung dan memperhitungkan, ketepatan menyetor, serta mengisi dan memasukkan surat pemberitahuan (SPT) wajib pajak, maka diharapkan semakin tinggi tingkat kepatuhan wajib pajak dalam melaksanakan dan memenuhi kewajiban pajaknya (Tika, 2016). Indikator variabel dependen dalam penelitian ini diukur dengan kepatuhan Wajib Pajak untuk menyetorkan kembali Surat Pemberitahuan (SPT) tahunan.

\section{Variabel Independen}

Variabel bebas merupakan variabel yang mempengaruhi atau menjadi sebab perubahannya atau timbulnya variabel dependen atau terikat (Sugiyono, 2013: 4). Selanjutnya penjelasan variabel bebas untuk penelitian.

Pengetahuan Perpajakan. Pengetahuan Perpajakan adalah dimana Wajib Pajak memiliki pengetahuan mengenai ketentuan umum dan tata cara perpajakan, sistem perpajakan, dan fungsi pajak. Pengetahuan Pajak adalah informasi pajak yang dapat digunakan Wajib Pajak sebagai dasar untuk bertindak, mengambil keputusan, dan untuk menempuh arah atau strategi tertentu sehubungan dengan pelaksanaan hak dan kewajibannya di bidang perpajakan. Pengetahuan Pajak adalah informasi pajak yang dapat digunakan wajib pajak sebagai dasar untuk bertindak, mengambil keputusan, dan untuk menempuh arah atau strategi tertentu sehubungan dengan pelaksanaa hak dan kewajibannya dibidang perpajakan (Caroko et al., 2015: 4).

Self Assesment System. Self-Assessment System merupakan sistem yang memberikan kepercayaan penuh kepada masyarakat selaku wajib pajak dalam melaksanakan kewajiban perpajakan. Kewajiban perpajakan yang dimaksud adalah "mendaftar, menghitung, membayar, dan melaporkan pajaknya sesuai dengan ketentuan perpajakan yang berlaku”. Self-Assessment System secara tidak langsung mengharuskan wajib pajak untuk memahami peraturan perpajakan agar mempermudah wajib pajak dalam melaksanakan kewajiban perpajakan dengan benar (Nurlaela, 2018: 3).

Sanksi Pajak. Sanksi adalah alat pemaksa, dimana sanksi memaksa menegakkan hukum atau memaksa mengindahkan normanorma hukum, sanksi sebagai alat penegak hukum bisa juga terdiri atas pembatalan perbuatan yang merupakan pelanggaran hukum, baik batal demi hukum maupun batal setelah ini dinyatakan oleh hakim (Titis, 2018: 35).

Penerapan e-SPT. Pelaporan menggunakan e-SPT oleh wajib pajak ditujukan untuk mengatasi kelemahan dari SPT manual. Beberapa keunggulan dari e-SPT yang pertama yaitu membuat data perpajakan yang digunakan dapat terorganisir dengan baik, 
sehingga mempermudah perhitungan pajak terutang. Keunggulan kedua adalah kemudahan dalam membuat laporan perpajakan, sehingga lebih efisien dalam pelaporan perpajakan.

Nasionalisme. Nasionalisme adalah persepsi wajib pajak mengenai rasa cintanya pada tanah air. Untuk mengukur tingkat kepercayaan pada pemerintah dan hukum digunakan instrumen daftar pertanyaan yang terdiri dari tujuh item pertanyaan menggunakan skala likert 1-5 (Purnamasari et al., 2017).

\section{Hasil Penelitian}

\section{Pengujian Asumsi Klasik}

Uji Normalitas. Uji normalitas digunakan untuk mengetahui apakah variabel yang dianalisis memenuhi kriteria distribusi normal (Ghozali, 2011: 44). Penelitian ini menggunakan uji normalitas dengan alat uji satu sampel Kolmogorov Smirnov (k-s). Kriteria pengujian jika nilai probabilitas value $>0,05$ maka lolos uji normalitas, sebaliknya jika nilai probabilitas value < 0,05 maka tidak lolos uji normalitas (Ghozali, 2011: 44). Berdasarkan hasil uji normalitas dapat disimpulkan bahwa model regresi ini berdistribusi normal, karena nilai signifikansi 2 tailed sebesar 0.200 lebih besar dari 0,05. Maka dapat disimpulkan bahwa data dalam penelitian berdistribusi normal.

$\begin{array}{ccr}\text { Uji } & \text { Multikolinieritas. } & \text { Uji } \\ \text { multikolinearitas } & \text { bertujuan } & \text { untuk }\end{array}$
membuktikan bahwa tidak ada korelasi antar variabel bebas dalam suatu penelitian. Model regresi yang baik seharusnya tidak terjadi korelasi antar variabel bebas. Untuk menguji multikolinearitas digunakan Variance Inflation Factor (VIF). Data penelitian dinyatakan bebas multikolinearitas apabila Tolerance $>0,1$ dan nilai VIF $<10$. Uji multikolinearitas variabel penelitian ini menggunakan aplikasi SPSS Statistic 23. Hasil dari perhitungan uji multikolinearitas dapat dilihat pada tabel berikut ini.

Berdasarkan hasil uji multikolinearitas menunjukkan bahwa tolerance dan VIF dari variabel pengetahuan pajak (X1) sebesar 0,552 dan 1,811, untuk variabel Self Assessment System (X2) sebesar 0,761 dan 1,314, untuk variabel sanksi pajak (X3) sebesar 0,619 dan 1,617, untuk variabel penerapan e-SPT (X4) sebesar 0,491 dan 2,038 dan untuk variabel nasionalisme (X5) sebesar 0,570 dan 1,755.
Oleh karena itu, dapat disimpulkan bahwa persamaan model regresi tidak mengandung masalah multikolinearitas yang artinya tidak ada korelasi diantara variabel-variabel bebas sehingga layak digunakan untuk analisis lebih lanjut karena nilai tolerance berada di atas 0,1 dan nilai VIF jauh dibawah angka 10.

Uji Heteroskedastisitas. Uji heteroskedastisitas bertujuan untuk meregresikan antara variabel bebas dengan variabel residual absolute, dimana apabila nilai sig $>0,05$ maka variabel bersangkutan dinyatakan bebas heteroskedastisitas. Jika terjadi heteroskedastisitas, artinya varians variabel dalam model tidak sama (konstan). Berdasarkan hasil uji heteroskedastisitas di atas, diperoleh hasil signifikasi pengetahuan pajak (X1) sebesar 0,966, variabel Self Assessment System (X2) sebesar 0,401, variabel sanksi pajak (X3) sebesar 0,227, variabel penerapan e-SPT (X4) sebesar 0,923 dan variabel nasionalisme (X5) sebesar 0,531. Berdasarkan nilai tersebut antara X1 hingga X5 lebih besar dari 0,05, sehingga artinya tidak terjadi heteroskedastisitas karena tingkat signifikasi lebih dari 0,05.

\section{Hasil Analisis Regresi Linier Berganda}

Analisis regresi berganda digunakan oleh peneliti, bila peneliti bermaksud meramalkan bagaimana keadaan (naik turunnya) variabel dependen (kriterium), bila dua atau lebih variabel independen sebagai faktor prediktor dimanipulasi (dinaikturunkan nilainya) (Sugiyono, 2013: 275). Persamaan umum regresi linear berganda adalah:

$$
\mathrm{Y}=\mathrm{a}+\mathrm{b}_{1} \mathrm{X}_{1}+\mathrm{b}_{2} \mathrm{X}_{2}+\mathrm{b}_{3} \mathrm{X}_{3}+\mathrm{b}_{4} \mathrm{X}_{4}+\mathrm{b}_{4} \mathrm{X}_{4}+
$$
$\mathrm{e}$

$$
\begin{array}{cl}
\text { Keterangan: } & \\
\mathrm{Y} & =\text { Kepatuhan pajak } \\
\mathrm{a} & =\text { Konstanta } \\
\mathrm{X}_{1} & =\text { Pengetahuan pajak } \\
\mathrm{b}_{1} & =\text { Koefisien pengetahuan pajak } \\
\mathrm{X}_{2} & =\text { Self Assesment System } \\
\mathrm{b}_{2} & =\text { Koefisien Self Assesment } \\
& \text { System } \\
\mathrm{X}_{3} & =\text { Sanksi pajak } \\
\mathrm{b}_{3} & =\text { Koefisien sanksi pajak } \\
\mathrm{X}_{4} & =\text { Penerapan e-SPT } \\
\mathrm{b}_{4} & =\text { Koefisien Penerapan e-SPT } \\
\mathrm{X}_{5} & =\text { Nasionalisme } \\
\mathrm{B}_{5} & =\text { Koefisien Nasionalisme } \\
\mathrm{e} & =\text { Error }
\end{array}
$$


Tabel 1. Hasil Uji Regresi Linier Berganda

\begin{tabular}{|c|c|c|c|c|c|c|}
\hline \multicolumn{7}{|c|}{ Coefficients $^{\mathrm{a}}$} \\
\hline & \multirow{2}{*}{ Model } & \multicolumn{2}{|c|}{$\begin{array}{l}\text { Unstandardized } \\
\text { Coefficients }\end{array}$} & \multirow{2}{*}{$\begin{array}{c}\begin{array}{c}\text { Standardized } \\
\text { Coefficients }\end{array} \\
\text { Beta } \\
\end{array}$} & \multirow[t]{2}{*}{ t } & \multirow{2}{*}{ Sig. } \\
\hline & & B & Std. Error & & & \\
\hline \multirow{6}{*}{1} & (Constant) & .721 & 1.878 & & .384 & .817 \\
\hline & TTL X1 & .141 & .122 & . 106 & 1.158 & .002 \\
\hline & TTL X2 & .068 & . 102 & .052 & .667 & .023 \\
\hline & TTL X3 & .248 & .089 & 241 & 2.788 & .008 \\
\hline & TTL X4 & .303 & .078 & .377 & 3.891 & .000 \\
\hline & TTL X5 & .235 & .060 & .355 & 3.947 & .000 \\
\hline
\end{tabular}

Sumber: Data diolah

Berdasarkan tabel 1 di atas, maka model regresi yang diperoleh adalah sebagai berikut:

$$
\begin{aligned}
& Y=0,721+0,141 X 1+0,068 X 2+0,248 X 3+ \\
& 0,303 X 4+0,235 X 5
\end{aligned}
$$

Dari persamaan regresi di atas dapat dijelaskan sebagai berikut:

1) Konstanta sebesar 0,721 menunjukkan bahwa jika variabel-variabel independen (pengetahuan pajak, Self-Assessment System, sanksi pajak, penerapan e-SPT dan nasionalisme) diasumsikan tidak mengalami perubahan (konstan) maka nilai Y (kepatuhan wajib pajak) adalah sebesar 0,721 satuan.

2) Koefisien variabel pengetahuan pajak sebesar 0,141 berarti setiap kenaikan variabel pengetahuan pajak sebesar 1 satuan, maka kepatuhan wajib pajak akan meningkat sebesar 0,141 satuan dengan asumsi variabel lain tidak mengalami perubahan atau konstan.

3) Koefisien variabel Self-Assessment System sebesar 0,068 berarti setiap kenaikan variabel Self-Assessment System sebesar 1 satuan, maka kepatuhan wajib pajak akan meningkat sebesar 0,068 satuan dengan asumsi variabel lain tidak mengalami perubahan atau konstan.

4) Koefisien variabel sanksi pajak sebesar 0,248 berarti setiap kenaikan variabel sanksi pajak sebesar 1 satuan, maka kepatuhan wajib pajak akan meningkat sebesar 0,248 satuan dengan asumsi variabel lain tidak mengalami perubahan atau konstan.

5) Koefisien variabel penerapan e-SPT sebesar 0,303 berarti setiap kenaikan variabel penerapan e-SPT sebesar 1 satuan, maka kepatuhan wajib pajak akan meningkat sebesar 0,303 satuan dengan asumsi variabel lain tidak mengalami perubahan atau konstan.

6) Koefisien variabel nasionalisme sebesar 0,235 berarti setiap kenaikan variabel nasionalisme sebesar 1 satuan, maka kepatuhan wajib pajak akan meningkat sebesar 0,235 satuan dengan asumsi variabel lain tidak mengalami perubahan atau konstan.

\section{Pengujian Hipotesis}

Pengujian hipotesis dalam penelitian ini menggunakan uji statistik t. Uji t dilakukan menggunakan aplikasi SPSS Statistic 23. Berdasarkan uji hipotesis dapat dijelaskan hasil penelitian ini sebagai berikut:

Hasil pengujian signifikansi pada variabel pengetahuan pajak memiliki nilai signifikan sebesar 0,002 yang berarti lebih kecil dari 0,05. Nilai koefisien sebesar 0,141 juga mendukung bahwa pengetahuan pajak berpengaruh terhadap kepatuhan wajib pajak, dengan demikian hipotesis pertama diterima.

Hasil pengujian signifikansi pada variabel Self-Assessment System memiliki nilai signifikan sebesar 0,023 yang berarti lebih kecil dari 0,05. Nilai koefisien sebesar 0,068 juga mendukung bahwa Self-Assessment System berpengaruh terhadap kepatuhan wajib pajak, meskipun tidak signifikan. Dengan demikian hipotesis kedua diterima.

Hasil pengujian signifikansi pada variabel sanksi pajak memiliki nilai signifikan sebesar 0,008 yang berarti lebih kecil dari 0,05. Nilai koefisien sebesar 0,248 juga mendukung bahwa sanksi pajak berpengaruh positif 
terhadap kepatuhan wajib pajak, dengan demikian hipotesis ketiga diterima.

Hasil pengujian signifikansi pada variabel penerapan e-SPT memiliki nilai signifikan sebesar 0,000 yang berarti lebih kecil dari 0,05. Nilai koefisien sebesar 0, 303 juga mendukung bahwa penerapan e-SPT berpengaruh positif terhadap kepatuhan wajib pajak, dengan demikian hipotesis keempat diterima.

Hasil pengujian signifikansi pada variabel nasionalisme memiliki nilai signifikan sebesar 0,000 yang berarti lebih kecil dari 0,05. Nilai koefisien sebesar 0,235 juga mendukung bahwa nasionalisme berpengaruh positif terhadap kepatuhan wajib pajak, dengan demikian hipotesis kelima diterima.

Uji F statistik F (uji signifikansi simultan) menunjukkan pada dasarnya apakah semua variabel independen (bebas) yang dimasukkan dalam model mempunyai pengaruh secara bersama-sama terhadap variabel dependen (terikat). Berdasarkan hasil perhitungan diperoleh nilai dari hasil uji $\mathrm{F}$ sebesar 0,000. Nilai uji F 0,000 lebih kecil dari tingkat signifikansi $\alpha=5 \%$, maka $\mathrm{H}_{0}$ ditolak. Sehingga variabel pengetahuan pajak, SelfAssessment System, sanksi pajak, penerapan eSPT dan nasionalisme secara bersama sama mempunyai pengaruh terhadap kepatuhan wajib pajak.

Koefisien Determinasi. Nilai Koefisien Determinasi adalah antara 0 atau 1 . Nilai $\mathrm{R}^{2}$ yang kecil berarti kemampuan variabelvariabel dependen amat terbatas. Dan sebaliknya, jika nilai yang mendekati 1 berarti variabel-variabel independen memberikan hampir semua informasi yang dibutuhkan untuk memprediksi variabel-variabel dependen. Berdasarkan hasil perhitungan nilai dari hasil uji adjusted R square sebesar 0,774. Nilai tersebut mengandung arti bahwa variabel $\mathrm{X} 1$ sampai X5 dapat menjelaskan variabel Y sebesar $77,4 \%$.

\section{PEMBAHASAN}

\section{Pengaruh Pengetahuan Perpajakan terhadap Kepatuhan Wajib Pajak}

Hasil pengujian signifikansi pada variabel pengetahuan pajak memiliki nilai signifikan sebesar 0,002 yang berarti lebih kecil dari 0,05 . Nilai koefisien sebesar 0,141 juga mendukung bahwa pengetahuan pajak berpengaruh terhadap kepatuhan wajib pajak, dengan demikian hipotesis pertama diterima. Hal tersebut sebagaimana penelitian yang dilakukan oleh Ria (2016) mengatakan bahwa Pengetahuan Perpajakan, memiliki pengaruh positif terhadap kepatuhan wajib pajak. Wajib Pajak yang memiliki pengetahuan tinggi terhadap ketentuan umum dan tata acara perpajakan, pengetahuan mengenai sistem perpajakan di Indonesia. Pengetahuan mengenai Fungsi Perpajakan akan mempermudah dalam melaksanakan kewajiban perpajakannya. Memahami ketentuan umum dan tata acara perpajakan akan mengurangi kesalahan Wajib Pajak dalam mengisi dan melaporkan Surat Pemberitahuan Pajak (SPT), menghitung jumlah pajak terutang serta menyetorkan pajak.

\section{Pengaruh Self Assesment System terhadap Kepatuhan Wajib Pajak}

Hasil pengujian signifikansi pada variabel Self Assessment System memiliki nilai signifikan sebesar 0,023 yang berarti lebih kecil dari 0,05. Nilai koefisien sebesar 0,068 juga mendukung bahwa Self Assessment System berpengaruh terhadap kepatuhan wajib pajak. Dengan demikian hipotesis kedua diterima. Hal tersebut sesuai dengan penelitian Septiani (2014) menunjukkan bahwa variabel penerapan self assessment system berpengaruh secara signifikan terhadap kepatuhan wajib pajak, sedangkan variabel kemauan membayar pajak berpengaruh secara signifikan terhadap kepatuhan wajib pajak. Hasil penelitian Endang Satyawati dan Mardanung Patmo Cahjono (2017) menemukan bahwa penerapan Self Assessment System berpengaruh signifikan terhadap Kepatuhan Wajib Pajak.

\section{Pengaruh Sanksi Pajak terhadap Kepatuhan Wajib Pajak}

Hasil pengujian signifikansi pada variabel sanksi pajak memiliki nilai signifikan sebesar 0,008 yang berarti lebih kecil dari 0,05. Nilai koefisien sebesar 0,248 juga mendukung bahwa sanksi pajak berpengaruh positif terhadap kepatuhan wajib pajak, dengan demikian hipotesis ketiga diterima. Hal tersebut sebagaimana penelitian Dian Lestari Siregar (2017) menemukan bahwa Sanksi Pajak berpengaruh signifikan terhadap Kepatuhan Wajib Pajak Orang Pribadi. Sanksi perpajakan 
yang tegas bagi pelanggar ketentuan perpajakan akan menciptakan rasa takut kepada Wajib Pajak untuk lalai dalam memenuhi kewajibannya dalam membayar pajak.

\section{Pengaruh Penerapan e-SPT terhadap Kepatuhan Wajib Pajak}

Hasil pengujian signifikansi pada variabel penerapan e-SPT memiliki nilai signifikan sebesar 0,000 yang berarti lebih kecil dari 0,05 . Nilai koefisien sebesar 0,303 juga mendukung bahwa penerapan e-SPT berpengaruh positif terhadap kepatuhan wajib pajak, dengan demikian hipotesis keempat diterima. Hal tersebut sesuai dengan penelitian Christian Hidayat (2011) yang menyimpulkan bahwa penerapan e-SPT PPN berpengaruh secara signifkan terhadap kualitas informasi perpajakan, dan Lingga (2013) yang menyimpulkan bahwa penerapan e-SPT dan $e$ Filling memiliki pengaruh positif signifikan terhadap kepatuhan wajib pajak.

\section{Pengaruh Nasionalisme terhadap Kepatuhan Wajib Pajak}

Hasil pengujian signifikansi pada variabel nasionalisme memiliki nilai signifikan sebesar 0,000 yang berarti lebih kecil dari 0,05. Nilai koefisien sebesar 0,235 juga mendukung bahwa nasionalisme berpengaruh positif terhadap kepatuhan wajib pajak, dengan demikian hipotesis kelima diterima.

Hal tersebut didukung dengan penelitian Purnamasari (2017) dimana nilai koefisien regresi variabel nasionalisme sebesar 0,296 menyatakan apabila terjadi peningkatan nasionalisme sebesar satu satuan sedangkan variabel lain tetap, maka akan meningkatkan kepatuhan wajib pajak dalam membayar PBB sebesar 0,296.

\section{SIMPULAN}

Berdasarkan hasil analisis dan pembahasan sebelunya, dapat disimpulkan beberapa hal sebagai berikut:

1. Pengetahuan pajak pengaruh positif terhadap kepatuhan wajib pajak.

2. Self Assessment System berpengaruh terhadap kepatuhan wajib pajak.

3. Sanksi pajak berpengaruh positif terhadap kepatuhan wajib pajak.

4. Penerapan e-SPT berpengaruh positif terhadap kepatuhan wajib pajak.
5. Nasionalisme berpengaruh positif terhadap kepatuhan wajib pajak.

\section{KETERBATASAN}

Penelitian ini memiliki beberapa keterbatasan yang dihadapi peneliti antara lain:

1. Penelitian ini hanya dilakukan pada wajib pajak orang pribadi yang merupakan karyawan dan sales force PT Bumi Manunggal Kharisma Surakarta.

2. Penelitian menggunakan metode pengumpulan data berupa kuisioner sehingga ada kemungkinan responden tidak bersungguh-sungguh dengan berbagai alasan.

3. Penelitian ini hanya menggunakan lima variabel bebas yaitu pengetahuan perpajakan, Self-Assessment System, sanksi pajak, penerapan e-SPT dan nasionalisme. Sehingga tidak menutup kemungkinan masih ada variabel lain diluar kelima variabel tersebut yang mempengaruhi kepatuhan wajib pajak.

\section{REFERENSI}

Bayu Caroko., Heru Susilo \& Zahroh Z.A. 2015. Pengaruh Pengetahuan Perpajakan, Kualitas Pelayanan Pajak dan Sanksi Pajak terhadap Motivasi Wajib Pajak Orang Pribadi dalam Membayar Pajak. Jurnal Perpajakan (JEJAK), 1(1), 1-10.

Elfin Siamena, Harijanto Sabijono, Jessy D.L Warongan. 2017. Pengaruh Sanksi Perpajakan dan Kesadaran Wajib Pajak Terhadap Kepatuhan Wajib Pajak Orang Pribadi di Manado. Jurnal Riset Akuntansi Going Concern, 12(2), 917927.

Endang Satyawati, Mardanung Patmo Cahjono 2017. Pengaruh Self Assessment System dan Sistem Informasi Perpajakan terhadap Kepatuhan Wajib Pajak, JRAK, 13(35).

Fani Ayudea. 2013. Tingkat Kepatuhan Wajib Pajak Masih 52\%. http://www.suaramerdeka.com. 08 April 2013 23:58 WIB

Faradilla Savitri. 2017. Pengaruh Sanksi Perpajakan Terhadap Kepatuhan Wajib Pajak Orang Pribadi di Kantor Pelayanan 
Pajak Pratama Madiun. Jurnal Equilibrium, 5(1).

Firdaus Aprian Zuhdi. 2015. Pengaruh Penerapan e-SPT dan Pengetahuan Perpajakan Terhadap Kepatuhan Wajib Pajak (Studi Pada Pengusaha Kena Pajak yang terdaftar di KPP Pratama Singosari). Jurnal Perpajakan (JEJAK), $7(1)$.

Ghozali, Imam. 2011. Aplikasi Analisis Multivariate Dengan Program IBM. SPSS 19 (edisi kelima.) Semarang: Universitas Diponegoro

Jotopurnomo, Cindy., dan Yenni Mangoting. 2013. Pengaruh Kesadaran Wajib Pajak, Kualitas Pelayanan Fiskus, Sanksi Perpajakan, Lingkungan Wajib Pajak Berada terhadap Kepatuhan Wajib Pajak Orang Pribadi di Surabaya. Journal Tax \& Accounting Review, 1(1)..

Lina Nurlaela. 2018. Pengaruh Self Assessment System dan Sanksi Perpajakan Terhadap Kepatuhan Wajib Pajak Pada KKP Pratama Garut. Jurnal Wahana Akuntansi Vol. 03; No. 01; Tahun 2018 HImn. 001-011

Lingga, Ita Salsalina. 2013. Pengaruh Penerapan e-SPT terhadap Kepatuhan Pajak: Survei terhadap Pengusaha Kena Pajak pada KPP Pratama "X”. Jurnal Akuntansi, (5)1.

Masruroh, Siti \& Zulaikha. 2013. Pengaruh Kemanfaatan NPWP, Pemahaman Wajib Pajak, Kualitas Pelayanan, Sanksi Perpajakan Terhadap Kepatuhan Wajib Pajak (Studi Empiris pada WPOP di Kabupaten Tegal). Jurusan Akuntansi Fakultas Ekonomika dan Bisnis. Journal Of Accounting. Universitas Diponegoro.

Nur Hidayati. 2010. Pengaruh Pengetahuan Pajak dan Kesadaran Wajib Pajak Terhadap Kepatuhan Pajak. Jurnal Akuntansi, 4(1). Maret 2010

Nurlis Islamiah Kamil. 2015. The Effect of Taxpayer Awareness, Knowledge, Tax Penalties and Tax Authorities Services on the Tax Complience: (Survey on the Individual Taxpayer at Jabodetabek \& Bandung). ISSN 2222-1697 (Vol.6,
No.2). Hal. 1-9. Jurusan Akuntansi Fakultas Ekonomika dan Bisnis Universitas Mercubuana, Jakarta

Purnamasari, Apriani, Sukirman, dan Umi Pratiwi. 2017. Pengaruh Pemahaman, Sanksi Perpajakan, Tingkat Kepercayaan Pada Pemerintah dan Hukum, Serta Nasionalisme Terhadap Kepatuhan Wajib Pajak Dalam Membayar PBB-P2 (Studi Pada Wajib Pajak PBB-P2 di Kota Banjar, Jawa Barat). Jurnal Akuntansi dan Auditing Volume 14/ No. 1 Tahun 2017: 22-39

Rahmatika, Mufti. 2010. "Faktor-faktor yang Mempengaruhi Kesadaran Kewajiban Perpajakan pada Sektor Usaha Kecil dan Menengah (UKM) yang berada di Wilayah Jakarta Timur”. Skripsi, Universitas Islam Negeri Syarif Hidayatullah Jakarta, Jakarta.

Ratnawati, J. Dan R. Indah Hernawati. 2015. Dasar-Dasar Perpajakan. Yogyakarta: Deepublish

Ria Prasasti. 2016. Pengaruh Pengetahuan Tentang Pajak, Sanksi Pajak dan Pemeriksaan Pajak, Terhadap Kepatuhan Wajib Pajak, Dikantor Wilayah Direktorat Jendral Pajak Daerah Istimewa Yogyakarta Tahun 2016. Skripsi Fakultas Ekonomi Universitas Negeri Yogyakarta

Septiani Daniska Saputri. 2014. Pengaruh Penerapan Self Assessment System dan Kemauan Membayar Pajak Terhadap Kepatuhan Wajib Pajak Usaha Mikro Kecil dan Menengah di Surakarta. Naskah Publikasi Fakultas Ekonomi dan Bisnis Universitas Muhammadiyah Surakarta

Setiana, Sinta, Tan kwang en, and Lidya Agustina. 2010. Pengaruh Penerapan Sistem Administrasi Perpajakan Modern Terhadap Kepatuhan Wajib Pajak Bojonagara). Jurnal Akuntansi 2(2), 134-61

Siti Kurnia Rahayu. 2010. Perpajakan Indonesia. Yogyakarta: Graha Ilmu.

Sugiyono. 2013. Statistika Penelitian. Bandung: Alfabeta 
Tika Yuniastuti. 2016. Pengaruh Kesadaran Wajib Pajak, Pelayanan Fiskus, Sanksi Wajib Pajak, Pemahaman Wajib Pajak dan Sikap Rasional Terhadap Kepatuhan Wajib Pajak Orang Pribadi (Studi Empiris Pada WPOP Pribadi di KPP Pratama Surakarta sampai tahun 2016). Naskah Publikasi Fakultas Ekonomi dan Bisnis Universitas Muhammadiyah Surakarta

Titis Wahyu Adi. 2018. Pengaruh Pengetahuan Perpajakan, Sanksi Pajak Dan Kesadaran Wajib Pajak Terhadap Kepatuhan Wajib Pajak Badan Pada KPP Pratama Cilacap. Skripsi Fakultas Ekonomi UNY

Tryana Tiraada. 2013. Kesadaran Perpajakan, Sanksi Pajak, Sikap Fiskus Terhadap Kepatuhan Wpop di Kabupaten Minahasa Selatan. Jurnal EMB, 1(3), 999-1008

Waluyo. 2013. Perpajakan Indonesia. Jakarta: Salemba Empat 
JRAK, Volume 17, No.1 Februari 2021 